\title{
Syntagm in the Analysis of the Intonation Contour (Experimental Results)
}

\author{
Sahila Mustafayeva ${ }^{1}$ \\ ${ }^{1}$ Department of English Grammar of Azerbaijan University of Languages, Baku, Azerbaijan \\ Correspondence: Sahila Mustafayeva, Azerbaijan University of Languages,134, Rashid Behbudov str. AZ 1014, \\ Baku, Azerbaijan. Tel: 994-050-780-6458. E-mails: sahilamustafa@yahoo.com
}

Received: April 13, 2015 Accepted: May 4, 2015 Online Published: July 30, 2015

doi:10.5539/ijel.v5n4p99 URL: http://dx.doi.org/10.5539/ijel.v5n4p99

\begin{abstract}
The article deals with the syntagm in the analysis of the intonation contour. The elements organizing the discourse, its beginning and end are expressed more saliently with the help of intonation. The problem of studying the information structure within texts was instituted by scholars of the Prague School.

It is undeniable that the division of discourse according to the structure and intonation plays a very important role in determining it. The intonation includes three parameters: temporal, dynamic and melodic parameters. The main component of the intonation according to the time parameter is that the time strength is getting weaker at the end of the terminal syntagm. In the Azerbaijani language the time parameter depends on the second parameter-melodic component. As it makes it clear that it takes more time to pronounce the sentences which have the least phonemes and morphemes than the sentences which have the most phonemes and morphemes. The third component of the intonation is its intensity. The intensity inside sentences depends on the quality of the vowels which is realized inside them and the place of them inside a sentence.

The article includes the results of the phonetic experiment, in which sentences consisting of one or more syntagms (mostly two syntagms) are used.
\end{abstract}

Keywords: discourse, prosodic features, syntagm, intonation, contour, information

\section{Introduction}

The prosodic elements play a very important role in the interpretation of discourse. The elements which organize the discourse, its beginning and its end are expressed more saliently with the intonation. To send the information is considered to be one of the main features of discourse.

The problem of studying the information structure within texts was instituted by the scholars of the Prague School. Later in 1967 the information sending within the texts was seen in the articles of Halliday. Halliday was interested in sending the information within texts, and generally in studying the information structure, and the ways of its being sent.

\section{Scope of the Study}

Two categories of discourse information were distinguished: given information and new information.

\begin{tabular}{|c|c|}
\hline Cümlə - Sentence & Verilmiş və yeni Məlumat (Given and New Information) \\
\hline 1.It is the BOY who is petting the cat & (GIVEN) Verilmiş: X pişiyi saxlayır (X-is petting the cat) (NEW) Yeni: \\
\hline / Pişiyi saxlayan OĞLANDIR// & \\
\hline $\begin{array}{l}\text { 2. It is the CAT which the boy is petting. /Oğlanın } \\
\text { saxladığı PIŞiKDİR// }\end{array}$ & $\begin{array}{l}\text { (GIVEN) Verilmiş: oğlan } \mathrm{X} \text {-i saxlayır (The boy is petting the } x \text { )(NEW) } \\
\text { Yeni: } \mathrm{X}=\text { pişik (X= the cat) }\end{array}$ \\
\hline $\begin{array}{l}\text { 3.The one who is petting the cat is the BOY. /Pişiyi } \\
\text { saxlayan adam OĞLANDIR// }\end{array}$ & $\begin{array}{l}\text { (GIVEN) Verilmiş: } X \text { pişiyi saxlayır ( } X \text { is petting the cat } \text { (NEW) Yeni: } \\
X=\text { Oğlan }(X=\text { the boy) }\end{array}$ \\
\hline 4. What the boy is $p$ & (GIVEN) Verilmiș: Oğlan X saxlayır (The boy is petting the cat) (NEW) \\
\hline /Oğla & $=$ the cat) \\
\hline 5. $\mathrm{Tl}$ & niş: X pişiyi saxlayır ( $X$ is petting the cat) (NEW) Yeni: \\
\hline /OĞLAN pişiyi saxlayır// & $\mathrm{X}=\mathrm{og}$ glan $(X=$ the boy $)$ \\
\hline
\end{tabular}


As it is shown in the examples the same words have been written in capital letters. It marks that these words are stressed words. As Halliday claims intonation has a very great role in sending the discourse information. The information sender or the information receiver gets the goal of the information sender's through the intonation. Halliday states that one feature of the intonation is that it should definite the category of the sent information. Generally, Halliday was concerned about specifying the organization of information within the spoken texts. He related the organization to phonological realization, mainly to intonation. Among these phonological realizations, intonation has a very specific place. The inner organization of the information unit distributes the information within the texts. Halliday suggests that the speaker should place the new information before the given one. Besides, Halliday also states that sentences mark given and new information by stress or accent on particular words. It proves that the local stressed words always convey the new information.

We can see some important points from this presentation. Firstly, it is not clear whether the given or new status of the information is determined by the central form or by the effect of placing the 'focal stress' on different constituents of the sentences or by some other interactions of these two distinct systems.

Secondly, it somewhat misrepresents Halliday's position taking the view that 'Sentences signal given and new information' (our emphasis). Halliday repeatedly insists that it is speakers who signal information status.

Thirdly, Hornby and Clark and Clark attribute one focus of the information in each sentence. The one which directly refers to the Hallidaynian clause is sentence 5. All other sentences are realized in tow clauses. In Hallidaynian analysis each of these two clauses would be expected to contain information focus as is demonstrated in the similar examples discussed by Halliday (1967, p. 226).

//the one who painted the SHED last week// was JOHN//

//JOHN// was the one who painted the SHED // last week//

By analogy we would expect sentence number 3, for example, to be realised with two points of information focus:

//the one who is petting the CAT // is the BOY//

Fourthly, the term 'given' is no longer being used as an analytic term to describe the status of the referents of expressions within the clause (or tone group), but is being used of the presuppositions attributed to clauses within sentences.

This view of 'givenness' is picked up by other psycholinguistics - for instance, Sanford and Garrod, 1981.

Halliday states 'given' information is specified as being treated by the speaker as 'recoverable either anaphorically or situationally' and 'new' information is said to be focal 'not in the sense that mentioned, the speaker presents it being recoverable from the preceding discourse. Whereas this characterisation does discriminate between the status of information marked intonationally as 'given' or 'new' by the speaker, it is capable of being interpreted so as to embrace a wider ranger of other phenomena. As Dahl remarks: "The concepts of old and new information are used to explain such phenomena in langauge as intonation, stress and word order and the use of anaphoric devices" (1976, p. 37).

Chafe insists that given status should be restricted to "that knowledge which the speaker assumes to be in the consciousness of the addressee at the time of the utterance' (1976, p. 30)

A very different view if givenness is put foward by Clark. He takes the general view of 'given' status characterised by Chafe as 'what the listener is expected to know already'. Clark and Clark characterises information status thus:

... given information should be indentifiable and new information unknown ... listeners should be confident that the given onformation conveys information they can identify uniquely. They understand that it is nformation the speaker believes they both agree on and that the speaker is asserting his beliefs about. (1977, p. 92)

The Clarkian view of given status is to be observed in Sanford and Garrod (1981). They suggest a processing model which invokes the notion of scenario. They propose that the scenario enables referring to individuals to be made in the first instance by a definite noun-phrase, because they are already given in the representation.

Chafe insists that what Haviland and Clark are concerned with is not givenness (the term is used by Chafe) (1974), but definiteness (Chafe, 1979). He states that the givenness may coincide with definiteness and often does, but that it is perfectly possible to find combinations of definiteness and newnes.

To define the information unit depends on the movement of a tone, its intensity and the voice temp. 
It is undeniable that the division of discourse according to the structure and intonation play a very important role in determining it. Brown and Yule claim that the structural units in oral discourse are in the shape of speaking forms and they can be called as paratons. (Brown \& Yule, 1983). The information line gives a signal for the beginning of a new paragraph. Paraton denotes the beginning, and then it makes topic changes. A speaker expresses what he wants to say at the beginning. This process happens with the rising tone. The end of the paraton shows the end of discourse. This process happens with the lowing tone. The Azerbaijani linguist Veysalli doesn't agree with Brown and Yule. He states that they show the subjective side of the intonation more prominently. For example, they discuss the age, gender, dialectical relation of the participants, though they don't touch the intellectual side of this process. On the other hand, Veysalli claims that paraton can't be considered as means of determining unity of discourse because a tone cannot be used as means of determiner of intonation component. The process of determining syntagm in discourse is very important. Look at the example:

/Anar DÜNӘNDӘN gözümə dəymir// - it can be considered as one part of discourse, as the movement of a tone begins with the middle voice tone of a speaker then it rises on the word /dünəndən/ and then it is lowering slowly. And consequently, relatively complete intonation serves to organize the external organization of this sentence. But the rising-lowering of the tone also means the movement of the intensity or the strengthing of it. It can be considered as a sentence stress. However, with the word / DÜNӘNDӘN/ the time parameter is shown as well, but it is not relevant. As in the Azerbaijani language the relevancy of a temp is shown only in interrogative sentences. Ohməd dünəndən gözə dəymir? According to the discourse context, we can divide this sentence: beginning, middle and end and so we can get such a scheme:

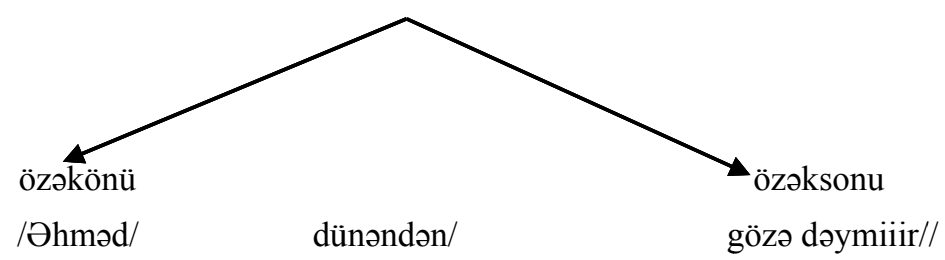

If we change the sentence into the interrogative sentence, the intonation contour will be like this:

Đhməd dünəndən gözə dəymiiir?

In the Azerbaijani language the masculine's voice temp is $280-300$ herse, the least minimal level is $80-90$ herse, but the feminine's is 300-500 herse, consequently between 150-300 hrs. The pitch prominent is stressed on the word which is considered to draw the listeners' attention. Let's look at the following example:

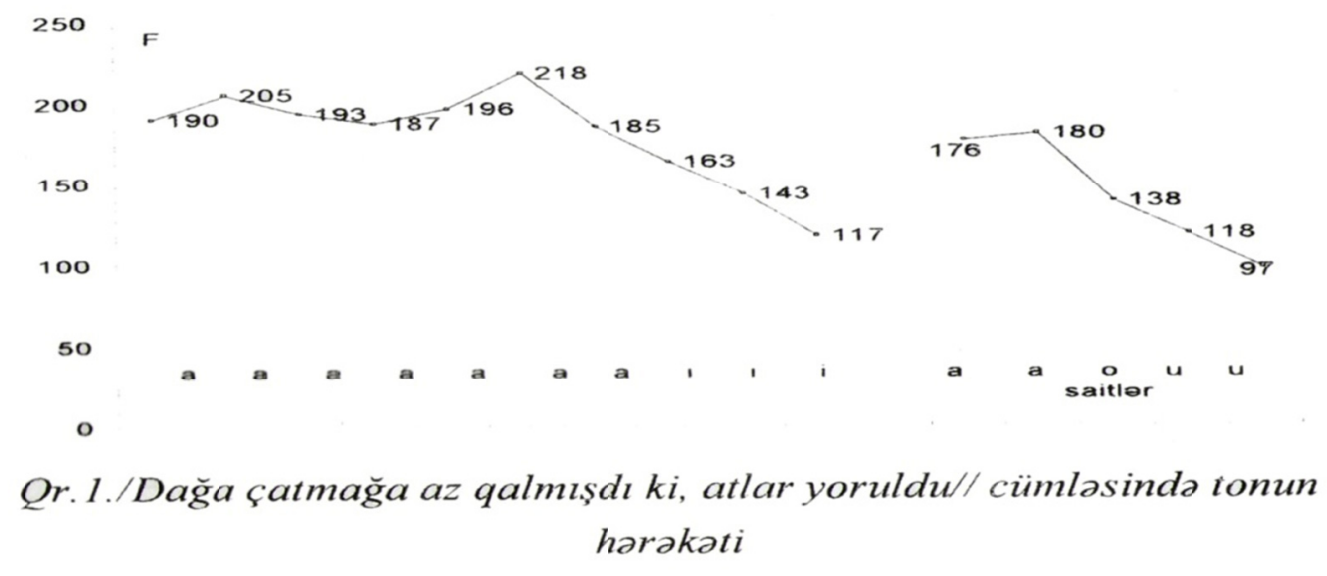

\section{Syntagm in the Analysis of the Intonation Contour}

This sentence has two syntagms. The pitch prominent is stressed on the word /az/, then it is getting lowered and at the end of the second syntagm it is $97 \mathrm{hrs}$. As the components of this sentence are joined with the conjunction $/ \mathrm{ki} /$ the intonation between the syntagms is weak. And here it is very suitable to mention the famous principles of compensation of Reshkovsky's. The interval between the first and the second syntagms equals $100 \mathrm{hrs}$. However, the distance between the pitch prominence of the first syntagm and the lowest tone of the second syntagm is 100 hrs (max. 218:min. 117=101 hrs), this point is like this in the second syntagm: 180: $97=83 \mathrm{hrs}$. It means that the 
syntagm has its melodic center and this center is pronounced in the rising tone in each syntagm. Look at Qr 1.

The next difference is shown between the rising and the lowering tones of the first and the second syntagms. Their correlation is 101:83 hrs. According to the communicative type of a sentence, it is a declarative affirmative sentence; it has very weak intonation at the end of the sentence.

The main component of the intonation according to the time parameter is that the time strength is getting weaker at the end of the terminal syntagm. On the other hand, in the Azerbaijani language the time parameter depends on the melodic component. As it is shown it takes more time to pronounce the sentences which have the least phonemes and morphemes than the sentences which have the most phonemes and morphemes. For example, it will take more time, if we pronounce the word /dağ/ than we pronounce the word /dağ hündürdür/.

The third component of the intonation is its intensity. The intensity inside the sentences depends on the quality of the vowels which is realized inside them and the place of them inside a sentence. In any case, the close vowels (/i, $\ddot{u}, \mathrm{e}, \ddot{o}, \mathrm{\partial} / \mathrm{)}$ have less intensity than the open vowels $(/ \mathrm{a}, 1, \mathrm{o}, \mathrm{u} /)$

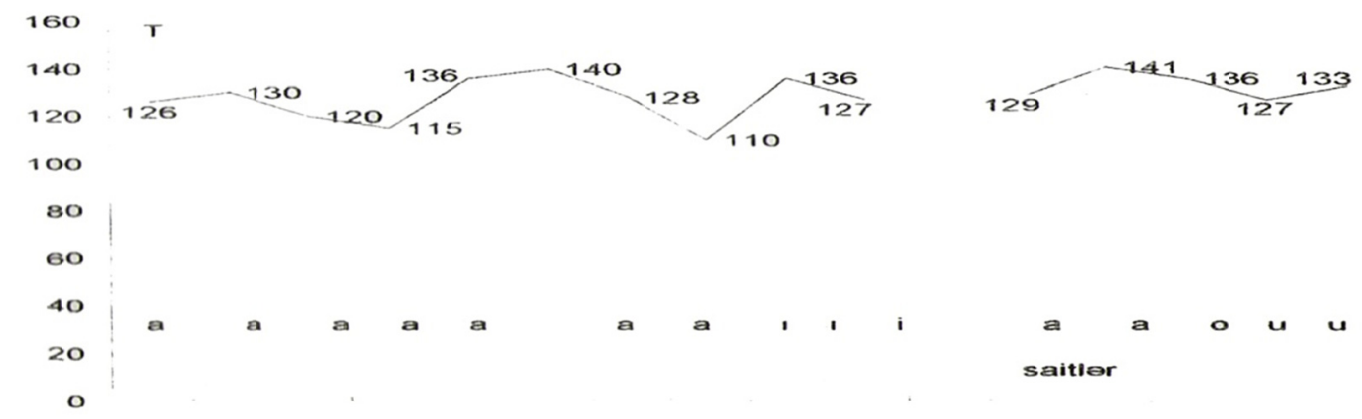

\section{Qr.2. /Dağa çatmağa az qalmışdı ki, atlar yoruldull cü̈mlasindo zaman parametrinin harakati}

The time parameter in the sentence.

/Dağa qalxmağa az qalmışdı ki, atlar yoruldu//

While researching according to the intensity, it is better to use the vowels of the same quality at the beginning as well as at the end of the sentences:

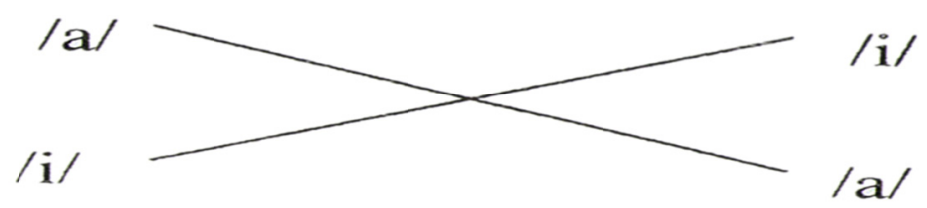

While doing the experiment, it is very important to consider the consonant surrounding and the approach to the stress. /Dağa qalxmağa az qalmışdı ki, atlar yoruldu// in this sentence the vowel /a/ is used at the beginning syntagm seven times, twice in the second syntagm. The general dynamic structure of the sentence is the same. The minimal and the maximal level in the first and the second are in the same correlation 74:56 and 79:57. The intensity in the first level is high in the first syntagm.We'd like to stress that even the least intensity is higher than the second one.: 


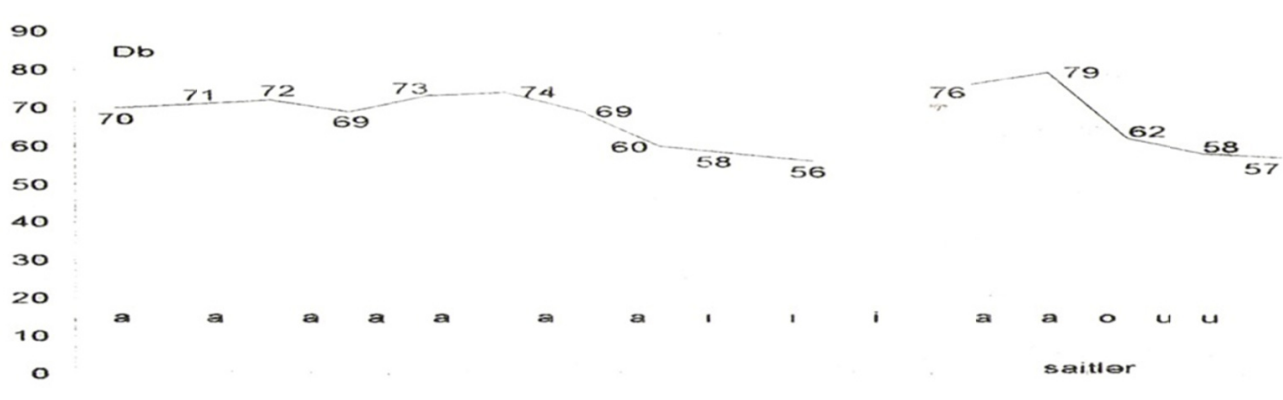

\section{Qr.3. /Dă̆a çatmă̆a az qalmışı ki, atlar yoruldul/ cümlasinda intensivliyin harakati.}

The analyzed sentence consists of two syntagms. /As it was snowing// (Qar yağdığından), /they were late for work// (Onlarişəyubandılar). /As it was snowing// (Qaryağdığından) - the middle tone frequency is $134 \mathrm{hrs}$ in the progredientsyntagm though it is $129 \mathrm{hrs}$ in terminal syntagm. The interval difference in the main tone indicator between syntagms is $6 \mathrm{hrs}$. The maximal tone frequency is observed at the beginning phase of syntagms. It is $146 \mathrm{hrs}$ in the first syllable in the first syntagm; in the second syntagm the frequency peak is observed in the second syllable $-148 \mathrm{hrs}$. The minimum tone frequency is observed at the final syllable of terminal syntagm. It is $112 \mathrm{hrs}$. In the progredientsyntagm the minimum tone frequency is observed in the second syllable near the end. It is $125 \mathrm{hrs}$. It is increasing at the end of the very syntagm in the main tone frequency. It is $137 \mathrm{hrs}$. The incomplete thought is observed in that syntagm, and it is shown in the intonation contour. Such intonation contours are usually called progressive ones.

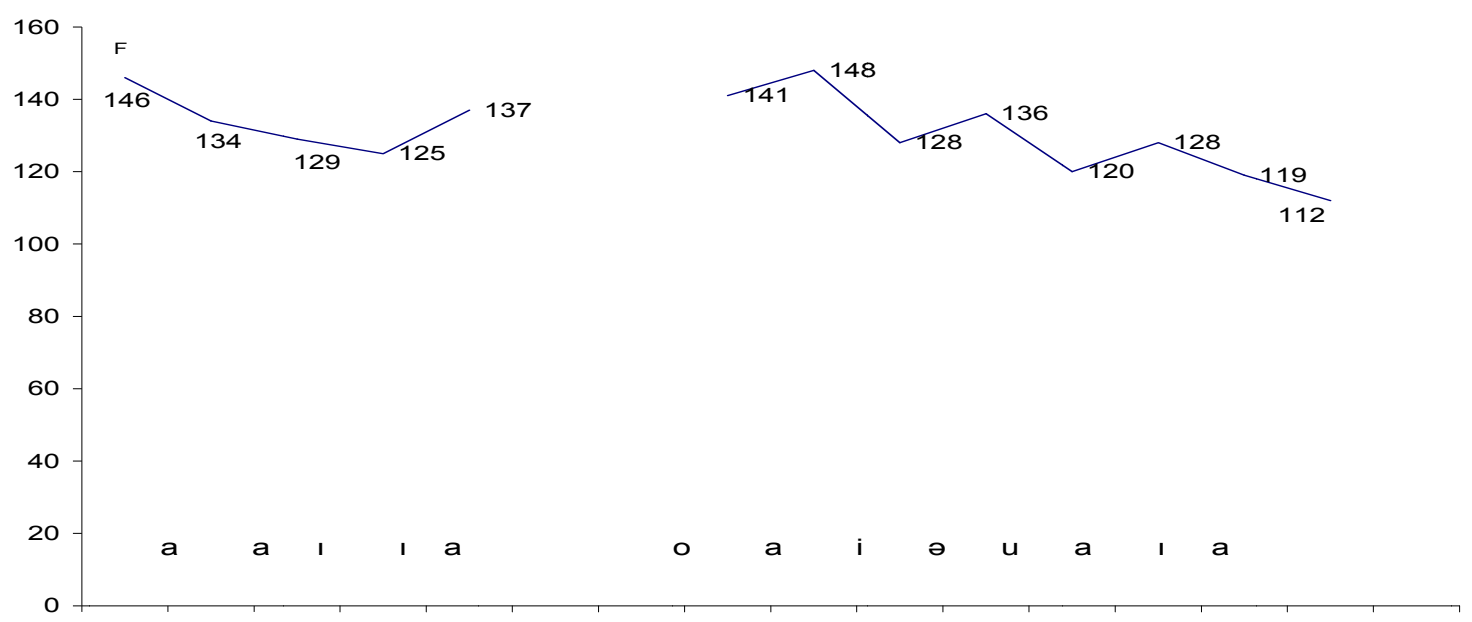

/As it was raining// (Qar yağdığından) /they were late for work// (Onlarişəyubandılar).In the analyzed sentence the dynamic indicators express the realization of declarative intonation contour. In the progredientsyntagm /As it was raining// (Qaryağdığından) the middle intensity in the progredientsyntagm is $55 \mathrm{db}$ though it is $33,7 \mathrm{db}$ at the terminal syntagm. The interval difference in the intensity indicators between syntagms is $1,3 \mathrm{db}$. The intensity peak is observed at the beginning of both syntagms. It is $59 \mathrm{db}$ in the second syllable in the first syntagm; the intensity peak is noted in the third syllable in the second syntagm. It is $57 \mathrm{db}$. The minimum intensity is noted at the final syllable of the terminal syntagm. It is $51 \mathrm{db}$. The minimum intensity is noted in the final syntagm in the progredientsyntagm. It is $52 \mathrm{db} .52 \mathrm{db}$. 


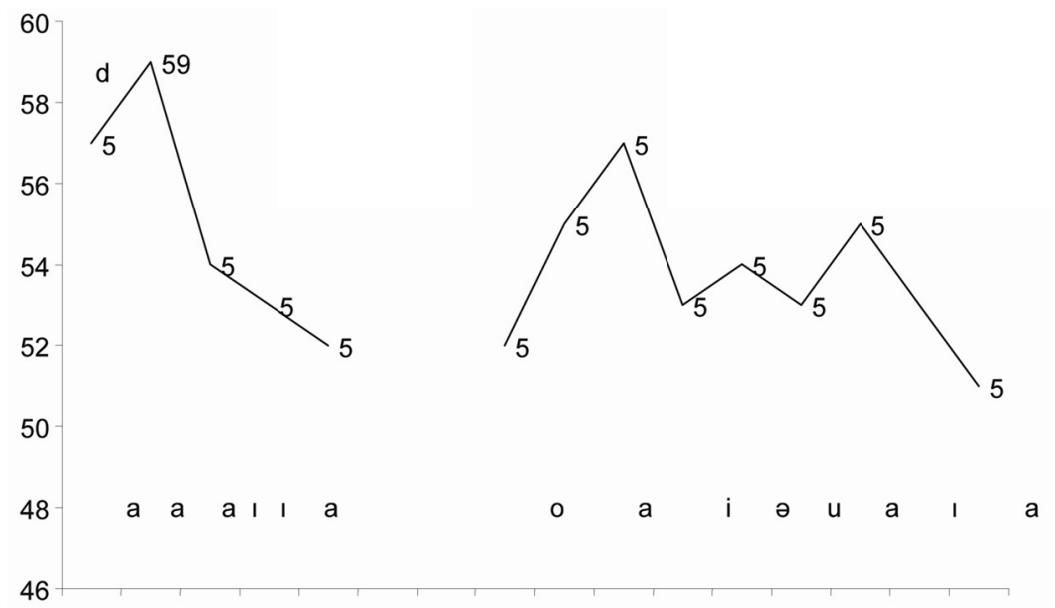

In the analyzed sentence /As it was raining//(Qaryağdığından), /they were late for work// (Onlarişəyubanırdılar) terminal indicators are divided according to the following correlation between syntagms. The frequency of the middle pronunciation in the progredientsyntagm is $101 \mathrm{~m} / \mathrm{san}$ though it is $72 \mathrm{~m} / \mathrm{san}$ in the terminal syntagm. The maximum time waste is noted in the second syllable in the progredientsyntagm. It is $130-128 \mathrm{~m} / \mathrm{san}$, the maximum time waste in the terminal syntagm is noted in the second syllable at the beginning. It is $90 \mathrm{~m} / \mathrm{san}$. But near the end of the terminal syntagm the lowering of the pronunciation temp is observed. It is $70 \mathrm{~m} / \mathrm{san}$.
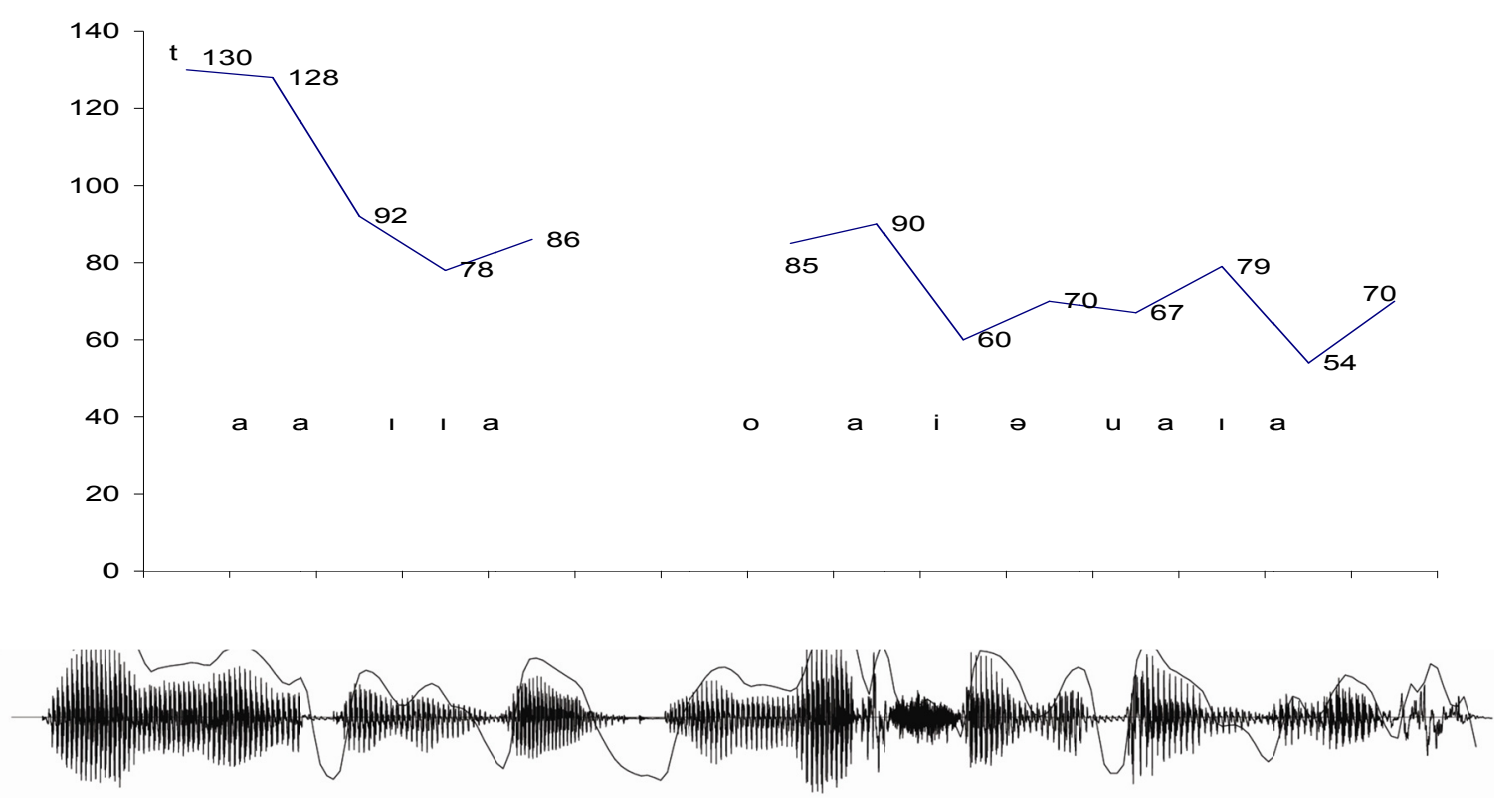

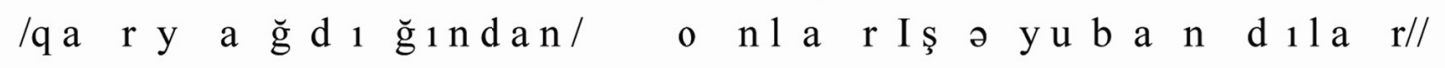

\section{Summary and Concluding Remarks}

We come to the conclusion that due to the results of the above mentioned experiments, each speaker makes a certain articular program for knowing his or her goal. At the same time, the speakers use certain acoustic signs. But this process is realized differently in different languages. In the Azerbaijani language the intensity can not be considered to be relevant, as it serves to mark and to serve the stress of a sentence syntagm. Temporal and melodic components can be relevent for the intonation.

The intonation analysis which we use for the sentence differs from those that are used to the apposition of the theme and rhema. The theme and the rheme of a sentence consists of two parts: topic and comment. The theme is the one that is spoken about, the rheme is the information given about the speaker. If we compare them with the sentence structure, the theme coincides with the subject, and the rheme with the predicate. 
Some call the theme as a discourse topic for the purpose of distingushing its grammatic characters. Though in this case discourse can also be considered as a propozition, not only a nominal element. It can be displayed as a whole fragment theme. Moreover, the title of the conversation can be the topic of it. For insatance, there is a TV program which is about the educational problem in a country. If we are asked such a question: "What is the program about? Or What is spoken there?" The answer may be like this: today's education. Or the problems of today's education. We can give any answer like these. It means that if a theme can be expressed either by a word or a word phrase, the topic of all discourse can be determined as its theme. Another example,

/gatar gəl'd:i/ - in this sentence in normal speech /gatar/ is the theme (the subject) and /galdi/ is the rheme (the predicate). It is possible to change this approach with the intonation and contrastive stress. For example, a man who is waiting for any of the vehicle (a train, a bus, a plane, etc.) coming and when he/she sees that any of them is approaching, he cries emotionally: /ga'tar, gəldi/ (only the train comes not the others). So, the theme of a sentence becomes the rheme. Such changes can often be seen.

So, there can be different kinds of discourse participants. But in any case, the participants who join the conversation should complete one another's speech. In the written discourse it is shown in paragraphs, etc. in the spoken discourse through the intonation, pause and other prosodic elements as well as their relation with syntagms.

\section{References}

Brown, G., \&Yule G. (1983).Discourse Analysis. New York:Cambridge University Press.

Chafe, W.L. (1974). Language and consciousness, Language 50. Universety of Chicago Press.

Chafe, W.L. (1979). The flow of thought and the flow of language. Universety of Chicago Press.

Halliday, M.A.K. (1967). Notes on transitivity and theme in English: Part 2.Journal of Linguistics, 3,199-244, Oxford University Press.

Məmmədov, A., \&Məmmədov, M. (2010). Diskurs təhlilinin koqnitiv perspektivləri.Bak1, Çaşığlu. (Mammadov A., \&Mammadov M.(2010).Cognitive principles of Discours Analysis.Baku).

Veysəlli, F.Y. (2010). Diskurs təhlilinə giriş. Təhsil, NPM. (Veysalli, F.Y.(2010). Introduction to discours analysis. Azerbaijan, Baku, Education Press).

Реформатский, А.А. (1979). Очерки по филологии, морфологии. Moscow. (Reformatski, A.A.(1979). Notes about philology, morphology).

\section{Copyrights}

Copyright for this article is retained by the author(s), with first publication rights granted to the journal.

This is an open-access article distributed under the terms and conditions of the Creative Commons Attribution license (http://creativecommons.org/licenses/by/3.0/). 